\title{
On the Timelessness of Music Dictionaries
}

\author{
Henning Bergenholtz, Department of Afrikaans and Dutch, University of \\ Stellenbosch, Stellenbosch, Republic of South Africa; and Centre for \\ Lexicography, Aarhus School of Business, Aarhus, Denmark (hb@asb.dk), \\ and \\ Inger Bergenholtz, Department of Music, University of Stellenbosch, \\ Stellenbosch, Republic of South Africa; and School of Music, Kolding, \\ Denmark(ibenholtz@mail.dk)
}

\begin{abstract}
A music dictionary for the Internet fulfils the same functions as printed music dictionaries. An earlier music dictionary is as useful as a new one if its information is correct. But the fact that an Internet dictionary can at any time be corrected according to modern practices makes it, if not timeless, at least more up to date. Furthermore, the possibilities of illustrating with picture and sound open a wide field of usefulness. Nevertheless the lexicographer has to be aware of the different needs of different user types in different user situations. The dictionary being discussed, Musikordbogen, has been designed for text reception rather than translation or text production. After the inception of the dictionary has been described, the way the possibilities of the Internet has influenced the concept and the content of the articles and the outer texts is discussed.
\end{abstract}

Keywords: MUSIC DICTIONARY, DICTIONARY FUNCTIONS, SPECIALIZED LEXICOGRAPHY, INTERNET LEXICOGRAPHY, TRANSLATION, TEXT RECEPTION, TEXT PRODUCTION, MUSICAL KNOWLEDGE

Opsomming: Oor die tydloosheid van musiekwoordeboeke. 'n Musiekwoordeboek vir die Internet vervul dieselfde funksie as gedrukte musiekwoordeboeke. 'n Vroeëre musiekwoordeboek is net so nuttig soos ' $n$ nuwe een indien sy inligting juis is. Maar die feit dat ' $n$ Internetwoordeboek enige tyd gekorrigeer kan word volgens moderne praktyke, maak dit, indien nie tydloos nie, ten minste meer op datum. Verder open die moontlikhede van illustrasie met prent en klank 'n wye veld van bruikbaarheid. Nogtans moet die leksikograaf bewus wees van die verskillende behoeftes van verskillende gebruikertipes in verskillende gebruikersituasies. Die woordeboek wat bespreek word, Musikordbogen, is beplan vir teksontvangs eerder as vertaling of teksproduksie. Nadat die ontstaan van die woordeboek beskryf is, word die manier bespreek waarop die moontlikhede van die internet die ontwerp en inhoud van die artikels en die buitetekste beïnvloed het.

Sleutelwoorde: MUSIEKWOORDEBOEK, WOORDEBOEKFUNKSIES, GESPESIALISEERDE LEKSIKOGRAFIE, INTERNETLEKSIKOGRAFIE, VERTALING, TEKSONTVANGS, TEKSPRODUKSIE, MUSIEKKENNIS 


\section{The concept "timeless"}

The title of this contribution about music lexicography is inspired by a headline in Die Burger of 26 March 2006: "WAT se waarde tydloos". A timeless dictionary would indeed help solving the problems of neither having enough dictionaries (cf. Bergenholtz and Gouws 2006), nor having the necessary money and manpower to update the completed dictionaries quickly enough. This headline was of course not written by a lexicographer who, more than anyone else, is aware of the changes and developments in the world and, dependent on these, in the languages of the world. Today a distinction between the music of Whites, Blacks and Coloureds as made in the foreword of The South African Music Encyclopedia (1979: i) would hardly be considered as essential for a music dictionary. And today a dictionary of molecular biology more than 15 years old would, for example, not be timeless because it would not describe the terms appropriately, due to the knowledge explosion in this field. In such a dictionary, there would be many serious lemma lacunae and even more incorrect lexicographical definitions. In other fields, one of these being music, similar explosive developments have not occurred. A music dictionary which is 100 years old will still be valid, if the information given in the entries is correct. It must come as a surprise to all ordinary dictionary users who regard their dictionary as infallible, that dictionary items are quite often wrong. The explanation for information errors in general language dictionaries concerning terms from specialized fields could be that they were not compiled by experts in the different fields. But this cannot be the only explanation, because the same and other wrong information is also found in specialized music dictionaries (often named music lexicons or music encyclopaedias). Nearly $50 \%$ of all terms in a Norwegian music dictionary from 1992 was faulty (see the review of Bergenholtz 1994). Almost all terms from the field of molecular biology in the big Norwegian national monolingual dictionary have incorrect lexicographical definitions, the explanations being not just incomplete, but outright erroneous (Bergenholtz 1996). Such errors are not only found in Norwegian dictionaries, they occur in dictionaries from most countries all over the world (cf. Bergenholtz 2007). Dictionaries from South Africa are no exception, as becomes clear from the following example from the South African Music Dictionary (2000: 156) where the abbreviations SH, A and E stand for Shona, Afrikaans and English respectively:

mbira [SH A E] (Shona tokkel-idiofoon • Shona plucked idiophone)

The mbira is an instrument employed in recreational activities and in ancestral communication. It is not only used by Shonas, but all over Southern and Eastern Africa, being called mbira or ikembe in different languages. This entry can therefore be justified by saying that the information is incomplete. This, however, is not the case with the following example from the South African Music Dictionary (2000: 156): 
mechanical instrument, clockwork instrument $[E]$ :

meganiese instrument [A]

meganiese instrument $[\mathrm{A}]$ : mechanical instrument, clockwork instrument [E]

A clockwork instrument is a very special type of mechanical instrument. The two English terms are therefore not synonymous. A single Afrikaans term as equivalent for the double lemma is incorrect as translation for both terms; only the direct translational term is correct.

A similar misrepresentation can be found in the following example from the South African Music Dictionary (2000: 158)

metallofoon [A] (Orff-instrument): metallophone [E]

(Orff instrument)

Orff-instruments are often metallophones, but this is not the only possibility. Metallophones are used all over the world, from the gambang in the gamelan music of Indonesia, to the vibraphones of Western symphonic music. Such limited information can only result in a misleading lexicographical item.

In other words, a dictionary cannot be called timeless if it contains entries with incorrect information. Such errors which are common, can easily be prevented. It is, however, much more difficult to avoid the biggest problem for dictionary users: The entry not containing the needed items for the intended dictionary function, which is to help a translator rendering text correctly, a native speaker writing his mother tongue or a non-native speaker using a foreign language.

\section{Dictionary functions}

In the modern lexicographical theory of functions (cf. Tarp 1992, Bergenholtz and Tarp 2003), the following lexicographical functions are assumed, with which a dictionary must comply in order to meet the needs of the expected users:

communicative functions: text production, reception, translation

cognitive functions: systematic want for knowledge, sporadic want for knowledge, ...

By communicative needs is meant help in solving a problem, which may arise in relation to reading, producing or translating a text. By cognitive needs is meant help in achieving actual or systematic knowledge of something, which may be a linguistic or a non-linguistic phenomenon or context. The context of cognitive needs may be illustrated by the following sequence of events which tells nothing about why or in which context the user wants more knowledge:

dictionary user $\rightarrow$ dictionary $\rightarrow$ dictionary user 
If the dictionary use is communication-related, a completely different sequence of events occurs. While reading, hearing, correcting, writing or translating a text, the user has come across a specific problem. Not knowing how to understand, correct, produce or translate a certain part of the text, he/she turns to a dictionary for help:

$$
\text { user } \rightarrow \text { text part } \text { paser } \rightarrow \text { dictionary } \rightarrow \text { user } \rightarrow \text { text } \text { part }_{\mathrm{z}}
$$

This does not mean that there cannot be a cognitive gain through a communication-related use of a dictionary. This may be the case, but it is not the intention for the use of the dictionary.

The lexicographical function of a given dictionary is to provide assistance to a specific user group with specific characteristics in order to cover the complex of needs arising in a specific type of use situation. A dictionary can have one or more functions, i.e. it can be mono- or multifunctional. As any other utility product, a dictionary also has a genuine purpose, which consists of the totality of its functions and the subject field(s) it covers. Experience shows that the determinant in a dictionary function is the use situation. The difference between a dictionary designed for text production in the user's native language and one designed for translation into a foreign language is much greater than, for example, the difference between a native-language production dictionary designed for adult users and one designed for school children.

This fundamental issue seems to be recognized by the compilers of the South African Music Dictionary (2000: 5):

The function of the dictionary is mainly to translate, rather than to explain. The main aim is to promote the standardisation of Afrikaans and English terminology

This means that it is not the function of this dictionary to provide its users with special information about the subject field. If the user does not know what a mbira is, it cannot be learnt from this dictionary. In cases with correctly given equivalents, such a dictionary serves as a first aid, but according to all discussions in the field of specialized bilingual lexicography, this is only a small part of the needed information. If the user does not know the plural of mbira, he/she could guess that it should be mbiras in English, and in Afrikaans too, but he/she cannot be sure. The dictionary does not contain any grammar information, which is much needed for translation. And there are no collocational items, e.g. if the user needs to translate the English pluck a mbira into Afrikaans. Furthermore, when double terms are given, the user is not told which one is the correct standardized term. A dictionary is not always a dictionary. Sometimes it should be called a word list.

\section{The concept of an Internet music dictionary}

In one aspect it should be expected that an Internet dictionary would be timeless, especially if it is regularly updated, partly by assistance of user emails and 
log-file analyses (cf. Bergenholtz and Johnsen 2005 and Prinsloo 2005). But this is not the case with printed dictionaries, which remain unchanged. It should be expected that printed dictionaries could be read many years after publication. This is not the case with electronic dictionaries. Almost all databased electronic dictionaries more than 10 years old can only partly, or at least not unproblematically, be read today if not regularly updated in the newest versions or transferred into other and more modern databases. This problem will not be dealt with here. Also, differences between electronic and printed dictionaries will not be discussed, except to say that both media try to fulfil the same dictionary functions.

The dictionary to be described is called Musikordbogen. It is an explanatory monolingual Danish music dictionary. The compilation was started during April 2005 in Denmark, was continued in Stellenbosch during the first part of 2006, and has, since its completion in August 2006, been accessible free of charge on the Internet at http://www. musikordbogen.dk. Musikordbogen (2006) is partly based on a printed dictionary, Politikens musikordbog (1995), which has a size similar to the South African Music Dictionary but contains fewer entries, about 3000 . However, it is no direct transformation from the printed to the electronic dictionary. All entries have been revised or rewritten and the systematic paragraphs on notation and music theory have been changed. There are many new entries. Until now, more than 500 lemmas have been added, as the length of an Internet dictionary has no financial implications. One of the main innovations consists of the dividing of the explanations to (a) a short definition/explanation, (b) a longer article with historical or other kinds of details and (c) an optional part with examples from music history. The printed version did contain references to other articles and the systematic paragraphs. In the Internet version, the access is made more easily as the user can just click on the references to switch from the article to the references and back. Apart from this, the Internet provides more varied possibilities as to illustrations, acoustic examples and www-links.

The intended functions of Musikordbogen can, on the one hand, be described as communication-orientated because the entries are meant to help laypersons and semi-experts with the reception of musical texts, be it music publications, radio programmes, musical notation etc. On the other hand, the systematic paragraphs contain overview articles on the principles of notation and music theory. Together with the more detailed parts of the explanations, they display the cognitive function of providing sporadic and systematic information about music for laypersons and semi-experts.

This dictionary is not meant for text production nor for translation. The translation of the cited articles and paragraphs would not have been possible by using the dictionary itself; a bilingual dictionary from and to English was employed.

The following description will give an idea of the structure of the dictionary. Obviously the actual layout of the entries seen on the Internet cannot be 
shown. In practice, when having gained access to Musikordbogen, a field will appear where the sought-for term can be entered. To a certain degree, the system, like the system found on Google, will foresee misspellings, asking the user to select the right word. The first part of the entry can be shown separately. This may be considered as a help for the text reception function (translations are from the Danish (HB and IB)):

mbira

a small African idiophone consisting of metal strips fixed on a resonating box of bamboo or wood, to be plucked with the thumbs of both hands

If the user should want the cognitive function containing detailed information about the item, he/she can click on the complete article:

mbira

a small African idiophone consisting of metal tongues fixed on a resonating box of bamboo or wood, to be plucked with the thumbs of both hands

The mbira is also called thumb piano. The tongues may be made of wood, and the resonating box takes on many different shapes. The instrument is found in most of Southern and Eastern Africa. The mbira is the national instrument of Zimbabwe and is used by the Shonas in religious ceremonies. Sometimes it is found under the name of ikembe and it is often accompanied by a rattle named hosho, which is a calabash filled with seeds.

$\rightarrow$ idiophone

= sansa

illustration

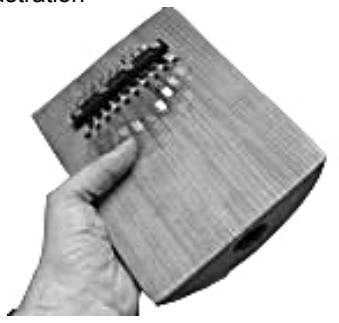

The article idiophone will appear after clicking on it. If an illustrative Internet address with a good picture of the instrument is found, hopefully with sound, it will appear in a separate field.

As mentioned above, a third part of the article will sometimes appear, mentioning examples from music history:

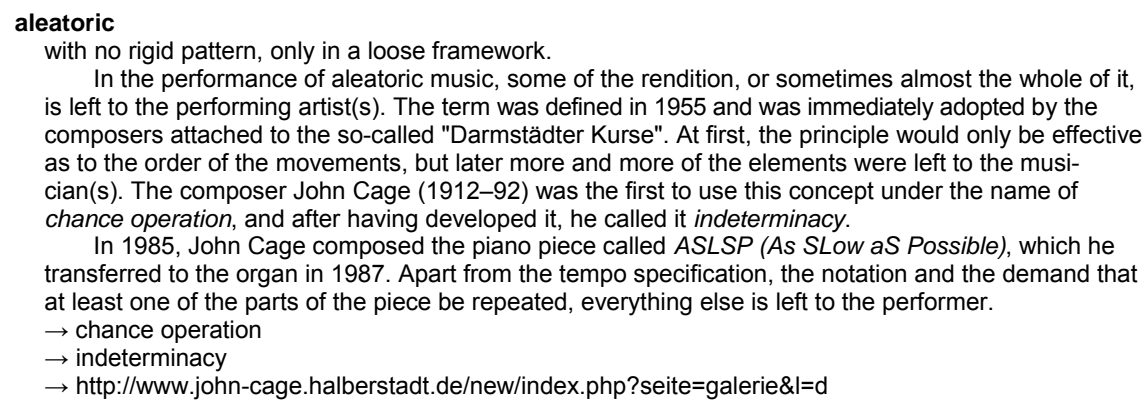

Sometimes the short explanation consists of only a translation of the term. 
Synonyms are marked with an equality sign and clicking on them will show their articles:

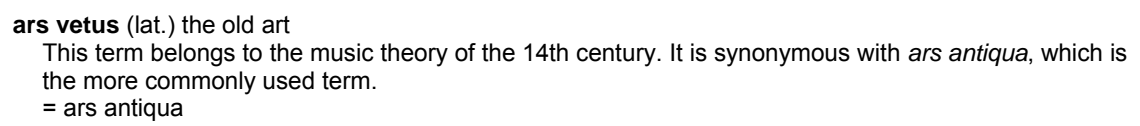

Under some terms, the user will be guided to the systematic paragraph, which elaborates on the music theory concerned.

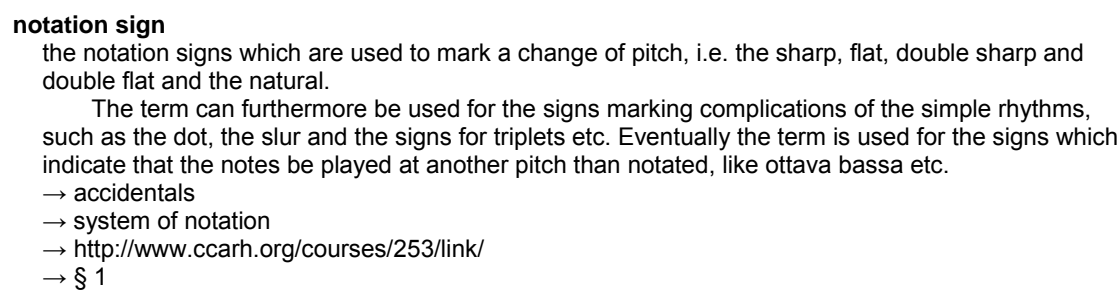

The systematic paragraphs consist of overview articles on the notation system and items from music theory, i.e. intervals, church modes, major and minor scales and their variants, the circle of fifths, and the structure of triads and other chords. At the end of the print version of the dictionary, illustrations of the normal arrangement of a Western symphony orchestra on stage and the range of the symphonic instruments and the human voice are given. These are substituted by references to Internet addresses and by pictures. Here again, the amount of information is no longer a problem, with no limitations on the size of the paper or the number of pages. This does not mean that there are no layout problems, but these should be left to experts on Internet design. Most of the systematic paragraphs comprise many illustrations in musical notation, which will appear as pictures in the running text. In the dictionary articles, they will be illustrations to be clicked on. If a term is given in bold letters, the user can click on the word, and the dictionary article will appear:

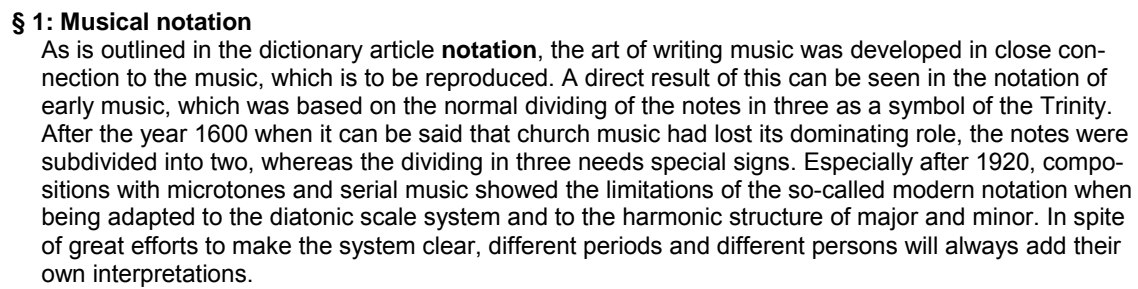
nection to the music, which is to be reproduced. A direct result of this can be seen in the notation of early music, which was based on the normal dividing of the notes in three as a symbol of the Trinity. After the year 1600 when it can be said that church music had lost its dominating role, the notes were subdivided into two, whereas the dividing in three needs special signs. Especially after 1920, compositions with microtones and serial music showed the limitations of the so-called modern notation when being adapted to the diatonic scale system and to the harmonic structure of major and minor. In spite of great efforts to make the system clear, different periods and different persons will always add their own interpretations.

§ 1.1 System of notation

In modern musical notation, the notes are written on staves consisting of five lines. If the melody moves from one line to the next space, it has moved one step. This means that a scale of 11 notes and 10 steps can be written on one staff:

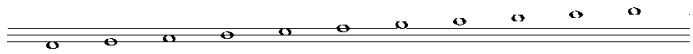

In a foreword to the systematic paragraphs, it is expressly mentioned that the paragraphs are not meant as a manual to music theory. If the user does not 
know anything about the principles of Western music theory, he/she will not understand the text. But the paragraphs can help him/her to obtain an overview of the items, they can serve to elucidate forgotten facts, and the switching to and from the dictionary articles can assist in acquiring a better understanding.

\section{Timeless dictionaries}

Every dictionary is a document of its time; every printed dictionary is already dated when it has gone through the correction and printing stages. This can be avoided in an Internet dictionary because the lexicographer(s) can work on it until the moment it is presented to the public. There is another difference between printed dictionaries and Internet dictionaries: Internet dictionaries are quite often finished within a year or two; printed dictionaries are as a rule the result of many years' work. This does not necessarily mean that dictionaries finished in a short time are of a low quality. In fact, when many printed dictionaries, which have been worked on for many years are considered, some of them, on the contrary, contain a large number of serious errors. This may easily be explained by the fact that compiling a dictionary could be compared to the work of Schiller's bell founders: If the bell is made "in einem Gusse", i.e. in one casting, the result will be more satisfactory.

\section{Literature}

Bergenholtz, H. 1994. Hvorfor ikke skrive af? Anmeldelse af: Leiv Flisnes: Musikordboken. [Oslo]: Tano 1992. LexicoNordica 1: 249-251.

Bergenholtz, H. 1996. Norsk international ordbog [review of the Norsk ordbok. Ordbok over det norske folkemålet og det nynorske skriftmålet. Band III. Flusker-Gigla. Edited by Reidar Bø, Arnbjørg Hageberg, Laurits Killingbertrø, Sigurd Norlie and Gunnar Pedersen. Oslo: Det Norske Samlaget 1994.]. Norsk Lingvistisk Tidsskrift 14: 75-84.

Bergenholtz, H. 2007. Falsche und richtige lexikographische Definitionen. Gottlieb, Henrik, Jens Erik Mogensen and Arne Zettersten (Eds.). Symposium on Lexicography XI. Proceedings of the Eleventh International Symposium on Lexicography May 2-4, 2002 at the University of Copenhagen: 125-132. Amsterdam/Philadelphia: Benjamins.

Bergenholtz, H. and R.H. Gouws. 2006. How to Do Policy with Dictionaries. Lexikos 16: 13-45.

Bergenholtz, H. and M. Johnsen. 2005. Log Files as a Tool for Improving Internet Dictionaries. Hermes 34: 117-141.

Bergenholtz, H. and S. Tarp. 2003. Two Opposing Theories: On H.E. Wiegand's Recent Discovery of Lexicographic Functions. Hermes, Journal of Linguistics 31: 171-196.

Brand, G. 2006. WAT se waarde tydloos. Staatsubsidie egter weer ingekort. Die Burger, 25 March: 18.

Musikordbogen = Inger Bergenholtz in Cooperation with Richard Almind and Henning Bergenholtz. 2006. Musikordbogen. http://www.musikordbogen.dk. 
http://lexikos.journals.ac.za

Politikens musikordbog = Inger Bergenholtz. 1995. Politikens musikordbog. Copenhagen: Politikens Forlag.

Prinsloo, D.J. 2005. Electronic Dictionaries Viewed from South Africa. Hermes 35: 11-35.

South African Music Dictionary = Reino Ottermann and Maria Smit (Chief Eds.), assisted by Izak Grove, Winfried Lüdemann, Heinrich van der Mescht and Caroline van Niekerk. 2000. SuidAfrikaanse Musiekwoordeboek/South African Music Dictionary. Compiled by a Revision Commission of the Suid-Afrikaanse Akademie vir Wetenskap en Kuns in Collaboration with the National Terminology Services. Second revised and enlarged edition. Cape Town: Pharos.

South African Music Encyclopedia = Jacques P. Malan (Gen. Ed.). 1979. South African Music Encyclopedia. Volume I A-D. Cape Town: Oxford University Press.

Tarp, S. 1992. Prolegomena til teknisk ordbog. Ph.D. dissertation. Aarhus: Department of Spanish. Aarhus School of Business. http://www.lng.hha.dk/dml/spa/phd.pdf [April 2006]. 